\title{
The effect of blended learning on developing critical thinking skills
}

\author{
Khaled Nahs Raqas Alotaibi \\ Department of Psychology, Education College, King Saud University, Riyadh, Saudi Arabia
}

Email address:

Kragges@ksu.edu.sa

\section{To cite this article:}

Khaled Nahs Raqas Alotaibi. The Effect of Blended Learning on Developing Critical Thinking Skills. Education Journal. Vol. 2, No. 4, 2013, pp. 176-185. doi: 10.11648/j.edu.20130204.21

\begin{abstract}
The present study aimed to investigate the effect of blended learning on developing critical thinking skills of a sample of students at Teachers' College in King Saud University. The study sample included 58 students who were divided randomly into two groups; one was an experimental group with 27 students and the other was a control group with 31 students. The following tools were used: E-courses, Watson - Glaser Critical Thinking Test (short form.)The researcher taught the experimental group using blended learning via Blackboard, while the control group was taught using traditional education. The results showed that: There were no statistically significant differences between the experimental group and the control group in critical thinking skills.
\end{abstract}

Keywords: Blended Learning, Critical Thinking, E-Courses, Watson - Glaser Critical Thinking Test

\section{Introduction and Literature Review}

E-learning has emerged as a model of learning due to the scientific and technological changes which the world is currently experiencing. As a result, the traditional methods are relatively unable to cope with these changes. Despite the advantages of E-learning, it has some shortcomings represented in the lack of face-to-face interaction which necessitates the availability of a new model combining some characteristics of both traditional learning and Elearning which can overcome the disadvantages of both kinds of learning. Thus, a more advanced model, Blended Learning (BL) has emerged. It combines the virtual learning environments with traditional learning environments as it is based on face-to-face learning as a form of synchronous learning as well as introducing information technology and telecommunications as an asynchronous model (Graham, 2006). Besides, it mixes a learning environment based on the Internet and a face-toface traditional environment in a complementary model which utilizes all possible means for both of them in the educational process (Littlejoin \& Pegler, 2006). Blended Elearning helps find convenient environments for students to achieve their aims more easily than in traditional learning environments through applying the most appropriate technologies in different contexts of classrooms and under different circumstances and hence cutting down the costs of learning (Korkmaz \& Karakusm, 2009).

The philosophy of Blended E-learning is based on the integration of the behaviorist theory which aims at conveying the previously specified information from the teacher to the student while the interest is in the succession of transmitting knowledge and sub-skills and the constructivist theory whose supporters think that the acquisition of knowledge can be achieved when the teacher himself / herself processes that knowledge in his / her constructivist informational framework (Xixiang, et al, 2010). Thus, Blended E-learning is one of the modern educational approaches that relies on the use of information technology in designing new educational contexts which increase active learning strategies and learner-centered strategies. In general, blended learning has some features of face-to-face learning and e-learning which makes it a new approach to creating educational programs capable of taking into account the individual differences between learners and bringing about distinguished learning as well.

Blended E-learning improves the effectiveness of learning through providing a better match between the requirements of learners and the educational program offered (Alkhan, 2005). In this respect, one report from the University of Tennessee indicated that Blended E-learning programs achieved better results of the levels of learning outcomes by $10 \%$ compared to the traditional form of learning inside classrooms and in a time less than half the time assigned to the program and for a less cost (Ibrahim, 
2007). More importantly, Blended E-learning guarantees the ease of communication with students as well as providing them with the material accompanied with drawings, pictures and sound effects which pave the way for a constantly interactive environment that promotes students' motivation and desire to keep learning. A study conducted by Siew-Eng et al revealed that Malaysian students feel satisfied when they use Blended E-learning in relation to learning and technical content, flexibility, social learning, motivation, participation, reaction and selflearning (Siew-Eng, et al, 2010 ).

Blended E-learning contributes to mixing classroom learning with virtual learning in order to achieve a kind of balance in the cost of preparing learning programs which helps reduce the cost of these programs (Twigg, 2003; Ibrahim, 2007 ). So, some researchers recommend that there be some balance in designing the educational materials by $50 \%$ representing face-to-face activities in classroom contexts and 50\% including virtual activities on the Internet (Korkmaz \& Karakusm, 2009) when designing the Blended E-learning environment.

The online e-leering and traditional classroom learning must be utilized and their accompanying disadvantages would be overcome so that the best learning outcomes which help learners to manage their time efficiently can be achieved (Riffell \& Sibley, 2003 ). Besides, Blended Elearning boosts learners' motivation to learn (Cameron, 2003) and it ensures offering immediate feedback to learners.

Blended E-learning is so flexible that it allows students to receive the same message from various sources in different forms in the long run. For example, a traditional lesson can be given and the same material can be presented in a different way online. A practical model of the same information can be presented as a symposium at a video conference.

On the other hand, the promotion of critical thinking skills is an educational objective because through these skills learners move from learning to thinking about what they learn and not what others have thought about. Thus, critical thinking helps make learners infer from what they read and understand and express that in their discussion with other people or in what they write. In this respect, critical thinking is one of the basic pillars of success in personal and academic life (Burkhart, 2006 ). However, some researchers think that critical thinking is one of the contemporary educational aims because the learners' ability to have these skills and use them in their daily life is one of the most important characteristics of the third millennium. Therefore, the individual who is capable of thinking critically is mentally independent and responsible for his / her decisions as he / she receives floods of information from various mass media on a daily basis (Mackinght, 2000 ).

Critical thinking skills have a wide-ranging interest as they are mental skills that can be successfully developed if there is an educational environment which includes training situations and interesting exercises to encourage trainees to think critically (Halpern, 1998 ). Some studies such as Bronson's (Bronson, 2008 ) and Korkmaz \& Karakuzm's (Korkmaz \& Karakuzm, 2009 ) indicate the possibility of developing critical thinking through some e-learning applications. Besides, Burges' study suggests that Blended E-learning motivates students to be self-dependent thinkers (Burges, 2009 ).

The mechanisms of implementing blended e-learning in the present study are based on using the Learning Management System (LMS) as it is the backbone of elearning which provides a common and integrated environment to manage all aspects of e-learning. There are many kinds of LMS such as Moodle, Blackboard and Jusur which are different in their features and capabilities, although they have some main components in common (Vice-deanship of Development and Quality, 2010) which are as follows:

- Course Management System.

- E-content Management System.

- Virtual Classrooms.

- Testing System.

- Synchronous and Asynchronous Systems.

- Students Management System.

When we try to understand the relationship between the uses of the LMS in blended learning we find it represented in a number of factors such as constant contact with students through interactive sessions, individual or collective e-mail, forums, postings, promotion of interaction and communication between students, publishing a to-do list for students to complete throughout the term, publishing electronic handouts, presenting enriching information and links related to the content of the lectures, giving an electronic lecture when attendance is difficult, publishing samples of previous exams and providing students with an electronic environment of cooperative learning (Vice-deanship of Development and Quality, 2010).

Bronson (Bronson, 2008 ) carried out a study to reveal the role of the environment of virtual classrooms on the Internet in developing critical thinking. The sample consisted of 43 students at the College of Medical Sciences and Nursing. The study used California's Test of Critical Thinking Skills. The pre-measurement of the critical thinking skills of the students was conducted before the experiment in both environments. However, the postmeasurement was conducted in a classroom environment. The most important findings of that study were the improvement of students' critical thinking skills in the environment of virtual classrooms, the development of students' critical thinking skills in the environment of traditional classrooms and the absence of statistically significant differences between both environments in terms of the critical thinking skills.

In addition, Akyuz and Samsa (Akyuz \& Samsa, 2009) carried out a study on the effect of the environment of Blended E-learning and the environment of traditional 
learning on developing critical thinking skills with a sample of 44 students in the Computer Course at Ankara University in Turkey. During that study, scientific discussions were conducted in classrooms and in chat rooms and forums on the Internet. A pre-measurement of the critical thinking skills was given before the experiment using Watson-Glaser's Test of Critical Thinking Skills. Five weeks later, a post-measurement was given. The findings showed no statistically significant differences between the pre-measurement and the post-measurement of the critical thinking skills. The researchers contributed that to the short period of training which did not exceed five weeks.

In another study carried out by Burges (Burges, 2009 ), the author examined the effect of a course based on WebCT on developing critical thinking, reading motivation and the teacher's role as a guide. The tools of WebCT were used such as discussion forums for four months as an educational design to develop critical thinking skills and reading motivation. The study came to the conclusion that there was some improvement on reading motivation and critical thinking skills through integrating this technology into the curricula. Moreover, the study showed that the way of integrating e-learning encouraged students to become self-dependent thinkers.

Korkmaz and Karakusm (Korkmaz and Karakusm,2009) carried out a study that aimed at identifying the model of effect of Blended E-learning on students' attitudes towards geography and critical thinking skills. The sample of the study consisted of two groups; one experimental with 28 students and the other control with 29 high school students in Turkey. The experimental group studied one page of the geography course through Blended E-learning, while the control group studied in the traditional way. The researcher used the geography-oriented test and California's Test to measure critical thinking preparations and skills. The study came to the conclusion that there was some positive attitude on the part of the experimental group students towards the geography course as well as more improvement on the critical thinking preparations and skills for the experimental group than for the control group.

\section{Question and Justification of the Research}

The question of the research lies in exploring the effect of Blended E-learning on developing critical thinking skills for a sample of students at Teachers' College in King Saud University. The researcher's interest in these variables is ascribed to a number of justifications:

Blended E-learning combines aspects of e-learning and aspects of traditional classroom learning. Some of the tools of e-learning can be used as part of real classroom learning through offering experiences that mix face-to-face learning with online learning. We have to think of remodeling the educational design on the framework of information technology
(Garrison \& Vaughan, 2008 ).

There is a relative lack of e-learning investment in developing students' critical thinking skills to build their positive mental ability to successfully deal with the increasingly rapid current changes because the crucial field of our age depends on spreading the culture of creative, critical thinking as people need to get the necessary information and use it effectively along with information technology.

- There is a need to address students' motivation to learn in an e-learning environment as the teacher tries to increase students' motivation to learn in a traditional learning environment while in the elearning environment when there is no teacher, the student finds help to boost his / her motivation and keep it high. A number of studies indicate that one of the most significant problems facing e-learning is the decrease in motivation to learn, and we find that learners in the e-learning environment are in dire need of strong motivation which enables them to learn just like their peers in a classroom environment without having to withdraw from an elearning situation (Miqdad, 2010; Leller \& Suzuki, 2004 ).

- The studies investigating the effect of Blended Elearning on developing critical thinking skills, the intrinsic motivation and academic achievement in the Saud culture are scarce. The present study might be one of the earliest studies on the Arab level to combine these variables. The question of the research can be put as follows:

What is the Effect of Blended E-learning in developing Critical Thinking Skills for a Sample of Students at Teachers' College in King Saud University

The following hypotheses stem from the main question of the study:

- There are statistically significant differences in the mean scores of the experimental group and the control group in relation to the critical thinking skills in favor of the experimental group.

- There are statistically significant differences in the mean scores of the pre-measurement and postmeasurement in relation to the critical thinking skills in favor of the post-measurement.

\section{Research Terminology}

\subsection{Blended E-Learning}

It is a mode of learning that combines face-to-face learning with e-learning, and it is the most favorable mode for many people presently especially after the emergence of the problem of merely relying on e-learning.

\subsection{Critical Thinking and its Skills}

Critical thinking is a complex kind of thinking that includes skills, attitudes and knowledge which all involve 
the individual's ability to identify problems and accept generalizations in case there is logical evidence to support them. It also involves the approaches to logical investigation, deduction, abstraction and generalization with an aim to identifying the value of this evidence and its validity, not to mention the application of these approaches and knowledge (Watson \& Glaser, 2008 ). The researcher defines critical thinking procedurally as the overall grade the student gets in Watson and Glaser' Test of Critical Thinking: Short Form which refers to the mean grade in all the dimensions: inference, distinction of assumptions, induction, interpretation, and argument assessment. We can further explain these as follows:

1. Inference: It is represented in the ability to distinguish between the degrees of the possibility of a conclusion being true or false according to the degree of its relatedness to specific facts offered to it. The procedural definition of this dimension is that it is the specific grade on Watson-Glaser's Test of Critical Thinking which is used to measure after the inference is made.

2. Distinction of Assumptions: This is represented in the ability to examine the facts and data included in some topic so that the individual decides that a certain assumption is acceptable or unacceptable according to whether or not it examines the given facts. The procedural definition is that it is the specific grade on Watson-Glaser's Test of Critical Thinking which is used to measure the skill of distinguishing the assumptions.

3. Implication: It is represented in the individual's ability to know the relations between certain given facts so that he / she can decide whether a conclusion is fully drawn from these facts or not in the light of this knowledge regardless of the validity of the given facts or the individual's attitude to them. The procedural definition is that it is the specific grade on Watson-Glaser's Test of Critical Thinking used to measure the implication skill.

4. Interpretation: It is represented in the individual's ability to draw a certain conclusion from facts assumed with reasonable certainty. The procedural definition is that it is the specific grade on WatsonGlaser's Test of Critical Thinking used to measure the interpretation skill.

5. Argument Assessment: it is represented in the individual's ability to realize the important aspects related to a certain matter and the ability to distinguish the strengths and weaknesses of that matter. The researcher defines it procedurally as the specific grade on Watson-Glaser's Test of Critical Thinking used to measure the skill of argument assessment.

\section{Research Procedures}

\subsection{Experimental Design}

The present study adopts the empirical approach which aims at exploring the effect of the independent variable on the dependent variable. The experimental design of this study is based on two groups; one experimental and the other control, and uses the pre-measurement and postmeasurement with both groups. The subjects of the sample were randomly selected and distributed to two groups. Then both groups were given a pre-measurement and a postmeasurement. After making sure that both groups were equivalent in terms of setting the variables (e.g. age) which would affect the results of the study, both groups experienced the independent variable of Blended Elearning, whereas the control group which studied via the traditional learning was deprived of that variable. After the experiment period was over, both groups were given a premeasurement test to measure the effect which the application of the independent variable had on the experimental group.

\subsection{Research Variables}

The research and its experimental design depended on the following variables:

1. Independent Variable: It represents Blended Elearning in this research that uses Blackboard as an LMS which is adopted by King Saud University.

2. Dependent Variables: Critical Thinking Skills.

3. Intrinsic Variables: They represent the length / period of time.

\subsection{Study Sample}

The sample comprises students from Teachers' College in King Saud University, and they are 58 regular students studying at Teachers' College in the second semester of the academic year 2011 / 2012. The sample was specifically chosen for the purposes of the experiment, and the students were put into two groups; experimental group with 27 students and control group with 31 students after the researcher made sure that following variables had been equivalent: age and pre-measurement of the critical thinking skills and intrinsic motivation. The participants were 18-24 years old with a mean of 19.68 years and a deviation standard of 00.95 . The researcher ensured that both groups are equivalent by means of the following:

\subsection{Setting the Intrinsic Variables}

The researcher made sure to set the variables that might interfere with the independent variable (Blended E-learning ) in its effect on the dependent variable (Critical Thinking, Learners' Intrinsic Motivation and Academic Achievement ). The following are the most important intrinsic variables which the researcher finds to affect the dependent variable:

1. Age: in order to exclude the effect of the age 
variable in the present study, the researcher chose to make the experimental group and the control group equivalent in terms of age. Therefore, he precisely calculated the significance of the differences in both groups by using the $\mathrm{T}$ - test. Table 1 shows the value of $\mathrm{T}$ and the statistical significance of the differences between both groups in terms of the age variable.

Table 1: the differences between the experimental group and the control group in the age variable

\begin{tabular}{cccccc}
\hline Variable & Group & Mean & DS & $\begin{array}{c}\text { T } \\
\text { Value }\end{array}$ & $\begin{array}{c}\text { Level of } \\
\text { Significance }\end{array}$ \\
\hline \multirow{2}{*}{ Age } & $\begin{array}{c}\text { Experimental } \\
\mathrm{N}=27\end{array}$ & 19.80 & 0.759 & & \\
& $\begin{array}{c}\text { Control } \\
\mathrm{N}=31\end{array}$ & 19.57 & 0.698 & & 0.194 \\
\hline
\end{tabular}

The table shows that the value of $\mathrm{T}$ was (1.31), and the indicator of statistical significance was $(0.194)$ which is statistically insignificant and refers to the fact that both the experimental group and the control group, were equivalent in terms of the age variable.

2. Pre-measurement of Critical Thinking: the researcher calculated the significance of the differences between both groups in terms of learners' intrinsic motivation using the T-test for the independent variables as shown in Table 2.

Table 2: The differences between the experimental group and the control group in the pre-measurement of critical thinking

\begin{tabular}{|c|c|c|c|c|}
\hline Variable & Group & Mean & DS & T Value \\
\hline \multirow{2}{*}{ Inference } & $\begin{array}{l}\text { Experimental } \\
\qquad \mathrm{N}=27\end{array}$ & 4.925 & 0.384 & \multirow{2}{*}{0.511} \\
\hline & $\begin{array}{l}\text { Control } \\
\mathrm{N}=31\end{array}$ & 4.871 & 0.427 & \\
\hline \multirow{2}{*}{$\begin{array}{l}\text { Distinction of } \\
\text { Assumptions }\end{array}$} & $\begin{array}{l}\text { Experimental } \\
\quad \mathrm{N}=27\end{array}$ & 6.444 & 0.577 & \multirow{2}{*}{1.061} \\
\hline & $\begin{array}{l}\text { Control } \\
\mathrm{N}=31\end{array}$ & 6.290 & 0.528 & \\
\hline \multirow{2}{*}{ Implication } & $\begin{array}{l}\text { Experimental } \\
\qquad \mathrm{N}=27\end{array}$ & 6.963 & 0.1922 & \multirow{2}{*}{-0.098} \\
\hline & $\begin{array}{l}\text { Control } \\
\mathrm{N}=31\end{array}$ & 6.967 & 0.176 & \\
\hline \multirow{2}{*}{ Interpretation } & $\begin{array}{l}\text { Experimental } \\
\qquad \mathrm{N}=27\end{array}$ & 7.000 & 0.000 & \multirow{2}{*}{-0.049} \\
\hline & $\begin{array}{l}\text { Control } \\
\mathrm{N}=31\end{array}$ & 7.000 & 0.000 & \\
\hline \multirow{2}{*}{$\begin{array}{c}\text { Argument } \\
\text { Assessment }\end{array}$} & $\begin{array}{l}\text { Experimental } \\
\qquad N=27\end{array}$ & 6.703 & 0.465 & \multirow[t]{2}{*}{-0.336} \\
\hline & $\begin{array}{l}\text { Control } \\
\mathrm{N}=31\end{array}$ & 6.703 & 0.461 & \\
\hline \multirow{2}{*}{$\begin{array}{l}\text { Overall Grade of } \\
\text { Critical Thinking }\end{array}$} & $\begin{array}{l}\text { Experimental } \\
\qquad \mathrm{N}=27\end{array}$ & 32.037 & 1.055 & \multirow[t]{2}{*}{0.0336} \\
\hline & $\begin{array}{l}\text { Control } \\
\mathrm{N}=31\end{array}$ & 32.129 & 1.024 & \\
\hline
\end{tabular}

\subsection{Research Tools}

Here the researcher explains the research tools which include:

- The course according to the electronic LMS (prepared by the researcher)

- Watson-Glaser's Test of Critical Thinking - short form (prepared by Alotaibi, in print )

\subsubsection{The Guidance Course according to the Electronic LMS}

The electronic LMS using Blackboard contains a homepage which is an introduction to the course through which its options can be edited and the content, activities, assignments and evaluation can be added. The system homepage includes the following components:

- Control Bar: It includes upper control elements which are links to the current user's settings, links to the homepage, instructions page and logging out of the system.

- Main Categories: They include the following:

- University: it contains the user's tools, information and preferences. It allows the user to add and delete units according to his / her preferences.

- Study Course: this allows the user to access the course he / she is studying in the current semester.

- Group: it contains a group of unmethodical courses or activity courses at the level of the department, college or university.

- Content Group: it contains a number of academic contents, preplanned and ready for use.

- Services: they provide a number of services which the system offers through the various activities of the university.

- Digital Library: it allows the user to access the services of the digital library provided by the university.

- Branch Categories: the branch categories which appear to the user differ according to main active categories.

- Adding Units: this allows the user to add typical units to the homepage where he / she can choose from various units provided by the system.

- Customization of the System Homepage: this allows the user to modify the appearance of the system as well as enabling him / her to rearrange the units on the page.

- $\quad$ Display Area: the units opted for by the user appear in this area.

The course of Students ' Guidance has been prepared and designed as an electronic course on the Internet in accordance with the elements above-mentioned. The course has been distributed according to its items over 15 weeks as follows:

1. Introduction to Students' Guidance

2. Fields of Guidance: children' guidance, guidance of teenagers and youth, guidance of the elderly and guidance of those with special needs. 
3. Guidance Theories: theory of psychoanalysis, behaviorist theory, theory of patient-centered therapy, theory of mental and emotional therapy.

4. Guidance Process: the context of the guidance process, methods of guidance, guidance relationships.

5. Tools of Guidance: interviews, notes, case study, comprehensive record, psychological tests.

6. Guidance responsibility at school: teacher guidance responsibilities, students counselor (counselor's academic and practical preparation, qualities, and guidance skills he / she should have ).

7. Psychological and social problems facing Saudi youth and ways of overcoming them.

In addition, there are a number of elements to which the students in the experimental group refer which are the forums related to the Students' Guidance aiming at fostering interaction and communication among students, setting various links to guidance psychology and uploading assignments and tests onto the system.

The students have been trained to deal with electronic LMS so that each student can log in to the electronic course page through his academic number. The students can log in to the website of the LMS on the following link: https://lms.ksu.edu.sa. Electronic office hours have also been specified so that the researcher can communicate with his students in the experimental group via the online contact system where he can answer his students' questions, offer solutions to the problems facing them in their study of the course. We can illustrate this further by looking at the following image of the program:

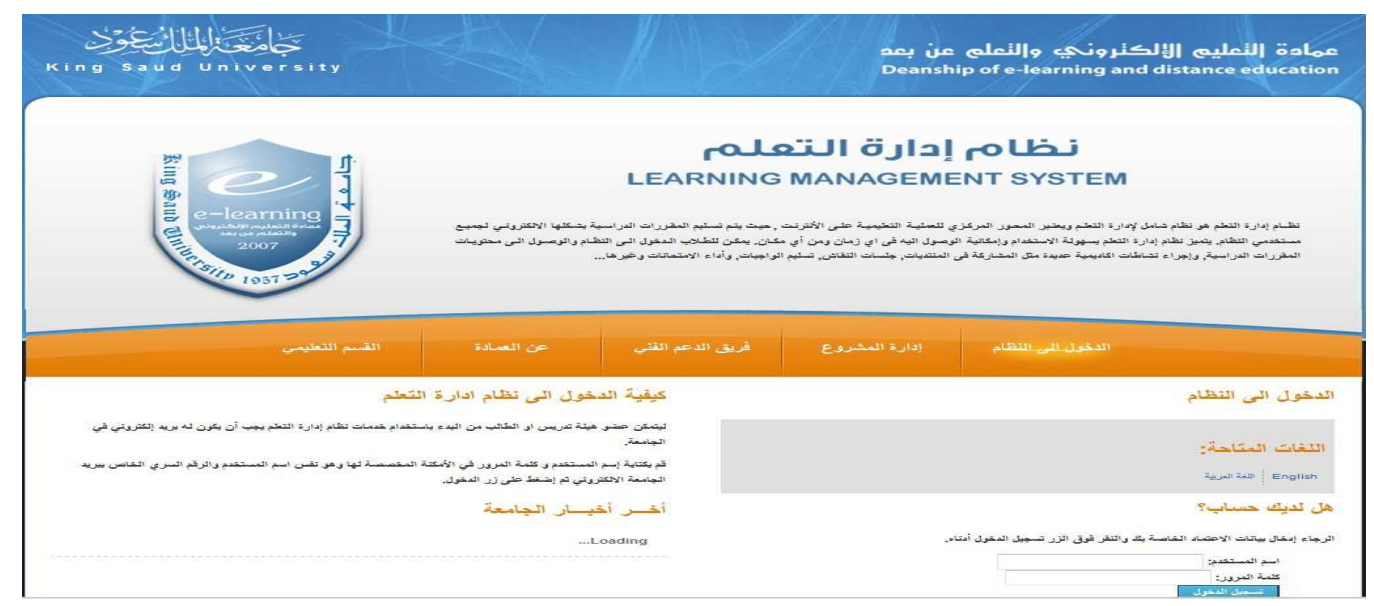

Image (1) shows the beginning of logging in to the electronic LMS

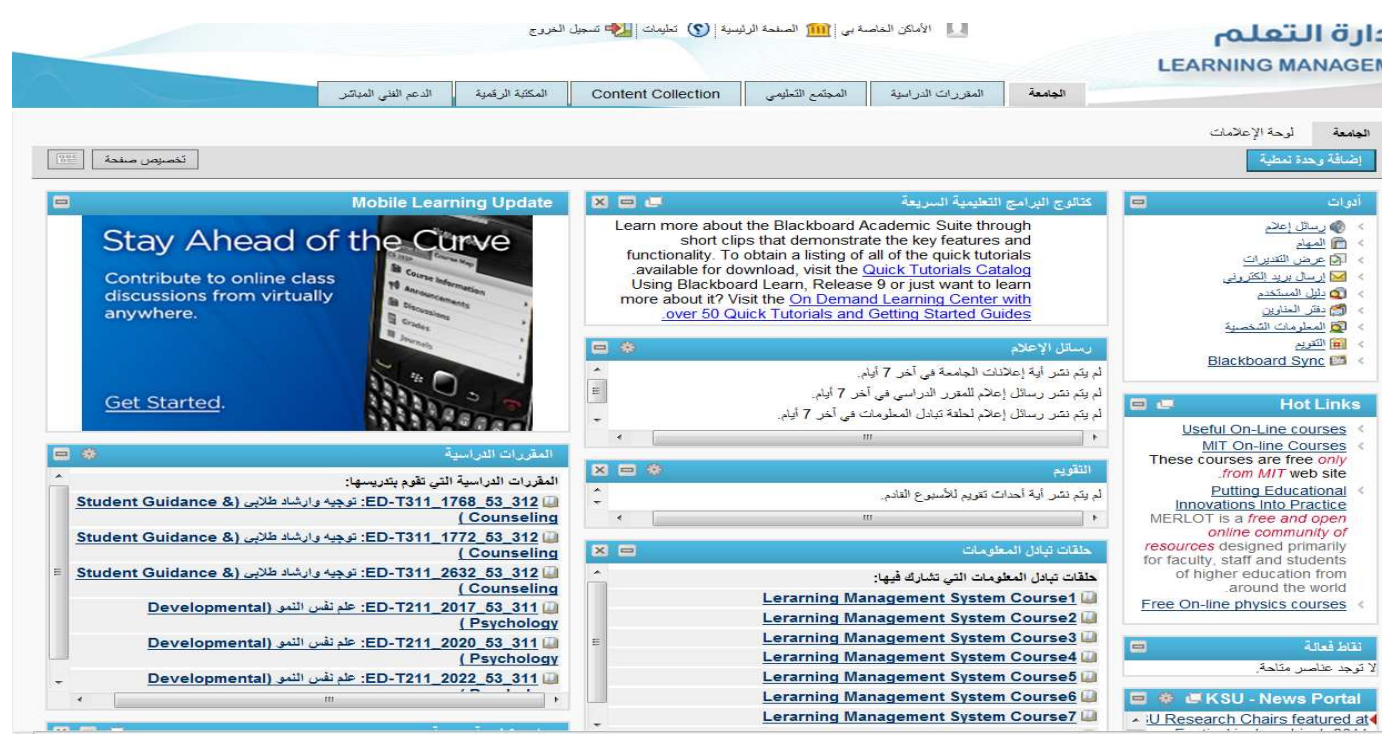

Image (2) shows the different components of the electronic LMS

The technical support unit at the Deanship of E-learning at King Saud University examined the electronic course in order to measure its validity. The remarks made by the technical support team were very enlightening.

\subsubsection{Watson-Glaser's Test of Critical Thinking - Short Form}

This test was prepared by Watson and Glaser in 1994 to help reduce the time required to answer the questions of the 
test. It was modeled on the original form of the test "Form $\mathrm{A}^{\prime}$ and is called "Form S". The test consists of 16 scenarios (problems ) measured in 40 items and requires 30 minutes to answer in addition to $5-10$ minutes for the test instructions. The test aims at measuring the ability of thinking critically, and includes 40 items which measure the following dimensions: inference, distinction of assumptions, implication, interpretation, and argument assessment. The researcher applied this test previously to a random sample of 400 students at Teachers' College in King Saud University who represented various scientific and theoretical majors. He also checked the coefficient validity of the test which measured five dimensions, and the values of the correlation coefficients between the dimensions and the total grade of the test ranged between $0.810-0.301$ which indicates its structural validity. Besides, the results of the study indicated that the test was related to a number of critical thinking tests; which refers to the validity of the test The coefficient of the test constancy by means of retesting was 0.78 and was 0.80 by means of Cronbach' Alpha. Thus, this test has some psychometric reliability characteristics (Alotaibi, 2012 ).

\section{Procedures of Experiment Execution}

1. The researcher chose two groups; one experimental with 27 students and one control with 31 students representing the sample of the study registered in the course of Students' Guidance at Teachers' College in King Saud University for the second semester of the year 2012 .

2. The researcher then gave the experimental group and the control group a pre-measurement as the first stage of carrying out the experiment at the beginning of the second semester of the academic year $1432 \mathrm{AH}$.

3. The researcher met with the members of the experimental group to train them to use the electronic LMS and how to view the content of the course with the help of one of the technical support team members at the Deanship of E-learning and Distance Learning.

4. The researcher taught the students of the experimental group the proposed course using the strategy of Blended E-learning which is based on mutual involovement of both the traditaional classroom learning and e-learning in one lecture provided that the lecture begins with the traditional classroom learning followed by e-learning, and the evaluation should be electronic for one full semester over 15 lectures.

5. The researcher encouraged the students of the experimental group to use the skill of asking

\footnotetext{
${ }^{1}$ The researcher would like to thank Mr. Khaled Abdulrahman Al-Saif, member of the technical support team at the Deanship of E-learning and Distance Learning, for his help and cooperation.
}

questions to develop their critical thinking in class and electronic contact hours during the lecture in order to be able to pass critical judgements through getting used to some technicalities such as learning how to ask, when to ask, what to ask, how to explain, when and how to explain the ways used?

6. As regards the control group, the researcher taught it using the traditional learning strategy of the course by depending on traditional lecturing in addition to the proposed textbook which is " Psychological and Educational Guidance " by Mahmoud Ata Hasan.

7. The post-measurement was then applied to both the experimental group and the control group at the end of the second semester of the academic year 2012 $\mathrm{AH}$. Later on, appropriate statistical analyses were conducted and duly discussed.

Review of Results: in this part of the study, the researcher reviews the results of the statistical analysis as follows:

\section{The Results Related to the First Construct Which States that}

Table 3: Differences in the mean scores of the experimental group and the control group in the post-measurement of Watson - Glaser's Test of Critical Thinking

\begin{tabular}{|c|c|c|c|c|c|}
\hline Variable & Group & Mean & DS & $\begin{array}{c}\mathbf{T} \\
\text { Valu } \\
\mathbf{e}\end{array}$ & $\begin{array}{c}\text { Level of } \\
\text { Significance }\end{array}$ \\
\hline \multirow{4}{*}{ Inference } & Experimenta & & & \multirow{4}{*}{$\begin{array}{c}- \\
0.870\end{array}$} & \multirow{4}{*}{ Insignificant } \\
\hline & 1 & 4.92 & 0.47 & & \\
\hline & $\mathrm{N}=27$ & & & & \\
\hline & $\begin{array}{l}\text { Control } \\
\mathrm{N}=31\end{array}$ & 5.00 & 0.00 & & \\
\hline \multirow{5}{*}{$\begin{array}{l}\text { Distinction } \\
\text { of } \\
\text { Assumptions }\end{array}$} & Experimenta & \multirow{3}{*}{6.777} & & \multirow{5}{*}{$\begin{array}{c}- \\
0.583\end{array}$} & \multirow{5}{*}{ Insignificant } \\
\hline & 1 & & 1.15 & & \\
\hline & $\mathrm{N}=27$ & & & & \\
\hline & Control & \multirow{2}{*}{6.903} & 0.30 & & \\
\hline & $\mathrm{N}=31$ & & 0 & & \\
\hline \multirow{4}{*}{ Implication } & Experimenta & \multirow[b]{2}{*}{6.481} & 1.18 & & \multirow{4}{*}{ Insignificant } \\
\hline & 1 & & 8 & - & \\
\hline & $\begin{array}{l}\mathrm{N}=27 \\
\text { Control }\end{array}$ & \multirow[b]{2}{*}{6.322} & 149 & \multirow[t]{2}{*}{0.444} & \\
\hline & $\mathrm{N}=31$ & & $\begin{array}{c}1.49 \\
1\end{array}$ & & \\
\hline \multirow{4}{*}{$\begin{array}{c}\text { Interpretatio } \\
\mathrm{n}\end{array}$} & Experimenta & \multirow[b]{2}{*}{6.333} & & \multirow{4}{*}{$\begin{array}{c}- \\
0.332\end{array}$} & \multirow{4}{*}{ Insignificant } \\
\hline & 1 & & $\begin{array}{c}1.92 \\
1\end{array}$ & & \\
\hline & $\begin{array}{l}N=27 \\
C o n t r o l\end{array}$ & & 150 & & \\
\hline & $\begin{array}{l}\text { Control } \\
\mathrm{N}=31\end{array}$ & 6.483 & $\begin{array}{c}1.52 \\
4\end{array}$ & & \\
\hline \multirow{4}{*}{$\begin{array}{l}\text { Argument } \\
\text { Assessment }\end{array}$} & Experimenta & \multirow[b]{2}{*}{6.666} & 117 & \multirow{4}{*}{$\begin{array}{c}- \\
0.392\end{array}$} & \multirow{4}{*}{ Insignificant } \\
\hline & $\begin{array}{c}1 \\
N=27\end{array}$ & & 6 & & \\
\hline & Control & \multirow{2}{*}{6.548} & 1.12 & & \\
\hline & $N=31$ & & 0 & & \\
\hline \multirow{6}{*}{$\begin{array}{l}\text { Overall } \\
\text { Grade of } \\
\text { Critical } \\
\text { Thinking }\end{array}$} & Experimenta & & & \multirow{6}{*}{0.002} & \multirow{6}{*}{$\begin{array}{c}\text { Insignifican } \\
\mathbf{t}\end{array}$} \\
\hline & 1 & 31.25 & 0 & & \\
\hline & $N=27$ & 9 & & & \\
\hline & & & & & \\
\hline & Control & 31.25 & & & \\
\hline & $\mathrm{N}=31$ & 8 & $\begin{array}{c}2.32 \\
3\end{array}$ & & \\
\hline
\end{tabular}


There are statistically significant differences in the mean scores of the experimental group and the control group in terms of critical thinking skills for the sample of the study in favor of the experimental group. To check this construct, the researcher used the T-test for the independent variables. Table 6 illustrates this.

It is clear from the results of Table 3 that there are no statistically significant differences between the experimental group and the control group in critical thinking skills which means that the first construct is not valid.

\section{The Results Related to the Second Construct Which States that}

There are statistically significant differences in the mean scores of the pre-measurement and the post-measurement of the critical thinking skills for the sample of the study in favor of the post-measurement. To check this construct, the researcher used the T-test of the correlated variables.

Table 4: Differences between the mean scores of the pre-measurement and the post-measurement in the critical thinking skills for the experimental group.

\begin{tabular}{|c|c|c|c|c|c|}
\hline Variable & Measurement & Mean & DS & T Value & Level of Significance \\
\hline \multirow{3}{*}{ Inference } & Pre $N=27$ & 4.925 & 0.384 & \multirow{3}{*}{-1.00} & \multirow{3}{*}{ insignicant } \\
\hline & & & & & \\
\hline & Post $N=27$ & 5.00 & 0.00 & & \\
\hline \multirow{3}{*}{ Distinction of Assumptions } & Pre $N=27$ & 6.444 & 0.57 & \multirow{3}{*}{-1.43} & \multirow{3}{*}{ insignicant } \\
\hline & & & & & \\
\hline & Post $N=27$ & 6.777 & 1.15 & & \\
\hline \multirow{3}{*}{ Implication } & Pre $N=27$ & 6.96 & 0.192 & \multirow{3}{*}{2.05} & \multirow{3}{*}{ insignicant } \\
\hline & & & & & \\
\hline & Post $N=27$ & 6.48 & 1.18 & & \\
\hline \multirow{3}{*}{ Interpretation } & Pre N=27 & 7.00 & 0.000 & \multirow{3}{*}{1.80} & \multirow{3}{*}{ insignicant } \\
\hline & & & & & \\
\hline & Post $N=27$ & 6.33 & 1.92 & & \\
\hline \multirow[b]{2}{*}{ Argument Assessment } & Pre $N=27$ & 6.70 & 0.46 & 0.146 & \multirow[b]{2}{*}{ insignicant } \\
\hline & Post $N=27$ & 6.66 & 1.17 & & \\
\hline \multirow{2}{*}{$\begin{array}{c}\text { Overall Grade of Critical } \\
\text { Thinking }\end{array}$} & Pre $N=27$ & 32.03 & 1.05 & \multirow[b]{2}{*}{1.36} & \multirow[b]{2}{*}{ insignicant } \\
\hline & Post $N=27$ & 31.25 & 255 & & \\
\hline
\end{tabular}

It is clear from the results of Table 4 that there are no statistically significant differences between the premeasurement and the post-measurement in critical thinking skills which means that Blended E-learning is ineffective in promoting critical thinking skills.

\section{Interpretation and Discussion of the Results}

By reviewing the results of the first construct, we notice that there are no statistically significant differences between the experimental group and the control group in the postmeasurement of the critical thinking skills at the end of the training period immediately. This clearly refers to the fact that Blended E-learning has no positive effect, and this finding is in keeping with the results of a study carried out by Akyuz \& Samsa (Akyuz \& Samsa, 2009) which indicated the absence of any positive effect for Blended Elearning on developing the critical thinking skills for the sample of students at Ankara University in Turkey. Besides, Bronson's study also referred to the fact that there are no statistically significant differences between students' performance in the virtual learning environment on the Internet and the traditional learning environment according to California' Test of Critical thinking skills (Bronson, 2008 ). This finding means that the performance of the experimental group on the Watson - Glaser's Test of Critical Thinking in the post-measurement was close to their performance in the pre-measurement. This also means that the critical thinking skills after the period of time specified for applying blended learning did not improve. The researcher ascribes this result to many factors, one of which is that the content of the materials does not foster critical thinking skills. In this particular context, Williams (Williams, 2003 ) suggested that the nature of the content of the course material which triggers off critical thinking should include questions and tasks that require thinking, not to mention the students' proficiency in practicing critical thinking. Similarly, some researchers think that developing critical thinking skills using blended learning should involve some educational activities that encourage critical thinking through managing synchronous and asynchronous electronic communication as well as activating the role of discussion forums (Akyuz \& Samsa, 
2009 ). In the same context, the results of the second construct suggest that there are no statistically significant differences between the pre-measurement and the postmeasurement in the critical thinking skills in favor of the post-measurement. This means that blended learning has no positive effect on developing critical thinking skills, and is out of keeping with Burges' study (Burges, 2009 ) and Korkmaz and Karakusm's study (Kokmaz \& Karakusm, 2009 ) and this refers to a development in critical thinking skills due to the use of blended learning. The fact that blended learning has no positive effect on developing critical thinking skills can be attributed to the idea that developing critical thinking skills via blended learning is not restricted to various educational tools only but students should also be perseverant and take the initiative in various discussion situations with other people without fear of being evaluated or cricized. Likewise, some researchers suggest that some university students are not adequately interested in developing critical, innovative and metainformational thinking skills. This makes them in need of more effective efforts to be made by various social institutions to upgrade their abilities (Alotoum, et al, 2009 ).

\section{Recommendations and Suggested Research}

- There should be more attention given to critical thinking skills in an academic environment in order to upgrade students' skills in various specialties.

- University staff members should be trained to use elearning methods in teaching rather than traditional methods which do not promote thinking.

- Electronic courses and teaching methods should be upgraded to meet the requirements of learning through an LMS in various programs at the university.

- $\quad$ More research needs to be done into the effectiveness of using blended learning in achieving better learning outcomes in various educational programs and courses.

- $\quad$ Staff members' motives for teaching through an LMS should be measured as there are some driving elements which affect the extent of their acceptance of teaching via an LMS (Gautreau, 2011 ).

- The effectiveness of using an LMS in developing critical thinking skills for a sample of university students should be duly investigated.

- The effect of self-conscious effectiveness on accepting Blended E-learning or refraining from Blended E-learning.

\section{Acknowledgment}

The authors extend their appreciate to the college of Education Research Center, Deanship of Scientific Research, King Saud University for funding this research work.

\section{References}

[1] Akyüz, H .I. \& Samsa, S. (2009)The effects of blended learning environment on the critical thinking skills of students. Procedia Social and Behavioral Sciences 1: 1744 1748

[2] Artion, A. R., Jr. \& Stephens, J. M. (2009). Academic motivation and self-regulation: A comparative analysis of undergraduate and graduate students in online courses. The Internet and Higher Education, 12, 146-151.

[3] Alotaibi, K. (2012). Psychometric properties of the WatsonGlaser Critical Thinking Appraisal Short Form. Journal of Education Sciences, 4, 1424-1454.

[4] Bronson, R.W (2008). Critical Thinking as an Outcome of Distance Learning: A study of Critical Thinking in a Distance Learning Environment. Ed.D, The George Washington University.

[5] Burgess, M. (2009) Using WebCT as a supplemental tool to enhance critical thinking and engagement among developmental reading students. Journal of College Reading and Learning, 39 (2) ,10-33.

[6] Burkhart, L. M. (2006)Thinking Critically about Critical Thinking: Developing thinking skills among high school students. , Ph.D., The Claremont Graduate University.

[7] Cameron, B. (2003). The effectiveness of simulation in a hybrid and online networking course. TechTrends, 47(5), $18-21$.

[8] Garrison, R., \& Vaughan, H. (2008). Blended learning in higher education: Framework, principles and guidelines. San Francisco: Jossey-Bass.

[9] Gautreau, C.(2011). Motivational Factors Affecting the Integration of a Learning Management System by Faculty. The Journal of Educators Online, 8(1),1-25.

[10] Graham, C. (2006). Blended learning systems. Definitions, current trends and future directions. In $\mathrm{C}$.Bonk \& $\mathrm{C}$. Graham (Eds.), The handbook of blended learning: Global perspectives, local designs .San Francisco: John Wiley and Sons.

[11] Halpern, D. F (1998) Teaching Critical Thinking for transfer across domains. American Psychologist. 53(4):449-455.

[12] Keller, J.M. and Suzuki, K. (2004). Learner motivation and E-learning design: a multinationally validated process. Journal of Educational Media, 29, (3): 229- 238.

[13] Korkmaz, Ö \& Karakusm, U (2009) the impact of blended learning models o student attitudes towards Geography course and their Critical Thinking dispositions and levels. The Turkish Online Journal of Educational Technology. 8, (4): 51-63.

[14] Lapman, M. (1988).Critical thinking what can it be? Education Leadership, 96, (1): 36-43.

[15] Littlejohn, A., \& Pegler, C. (2007). Preparing for Blended eLearning. London: Routledge.

[16] Mackinght, C (2000) Teaching Critical Thinking through online discussion. Education Quality, 2, 38-41 
[17] Reasons, C., Valadares, K. \& Slavkin, M. (2005). Questioning the Hybrid Model: student outcomes in different courses formats. JALN, 9(1), available on $23 \backslash 1 \backslash 2010$ from.http:// www.sl;anc.org $\backslash$ publications $\backslash j a l n \backslash u q n-r e a s o n . a$

[18] Riffell, S.K., \& Sibley, D.F. (2003). Using web-based instruction to improve large undergraduate biology courses: An evaluation of a hybrid course format. Journal of College Science Teaching, 44(3): 217-235.

[19] Siew-Eng, L; BT Ariffin, S; Rahman, S \& Kim-Leomg, L (2010). Diversity in education using blended learning in Sarawak. China Education Review, 7(2): 83-88.

[20] Twigg, C. (2003). Improving learning and reducing costs: New models for online learning. EducauseReview, 28-38.
[21] Vice-deanship of Development and Quality (2010). Training Portfolio on Using Blackboard as an LMS. Deanship of E-learning and Distance Learning. King Saud University.

[22] Watson, G \& Glaser, E. (2008). Watson-Glaser Critical Thinking Appraisal Short Form Manual. Pearson Education, Inc.

[23] Williams, R. (2003).Critical thinking as a Predictor and Outcome Measure in a Large Undergraduate Educational Psychology Course. ERIC NO: ED478075

[24] Xixiang, L; Zhang, X; Kede Qin, K \& GuangxueYue, G (2010). The Evaluation System for Blending Learning Based on Blackboard Academic Suite. Proceedings of the Second International Symposium on Networking and Network Security (ISNNS '10) Jinggangshan, P. R. China, 2-4, April. 2010, pp. 081-084. 